\title{
Guided bone regeneration
}

\author{
Young-Kyun Kim, DDS, PhD ${ }^{1,2,3}$, Jeong-Kui Ku, DDS, PhD, FIBCOMS $S^{4,5}$ \\ ${ }^{1}$ Editor-in-Chief of J Korean Assoc Oral Maxillofac Surg, ${ }^{2}$ Department of Oral and Maxillofacial Surgery, Section of Dentistry, Seoul \\ National University Bundang Hospital, Seongnam, ${ }^{3}$ Department of Dentistry \& Dental Research Institute, School of Dentistry, Seoul \\ National University, Seoul, ${ }^{4}$ Section Editor of J Korean Assoc Oral Maxillofac Surg, ${ }^{5}$ Department of Oral and Maxillofacial Surgery, \\ Section of Dentistry, Armed Forces Capital Hospital, Armed Forces Medical Command, Seongnam, Korea
}

\begin{abstract}
J Korean Assoc Oral Maxillofac Surg 2020;46:361-366)
Guided bone regeneration (GBR) is a surgical procedure that utilizes bone grafts with barrier membranes to reconstruct small defects around dental implants. This procedure is commonly deployed on dehiscence or fenestration defects $\geq 2 \mathrm{~mm}$, and mixing with autogenous bone is recommended on larger defects. Tension-free primary closure is a critical factor to prevent wound dehiscence, which is critical cause of GBR failure. A barrier membrane should be rigidly fixed without mobility. If the barrier is exposed, closed monitoring should be utilized to prevent secondary infection.
\end{abstract}

Key words: Bone, Wound, Membrane

[paper submitted 2020. 9. 10 / accepted 2020. 9. 14]

\section{Introduction}

Guided bone regeneration (GBR) is a bone graft procedure that uses a covering barrier membrane to block soft tissue invasion. Some scholars argue that GBR should be strictly defined as those cases using a barrier membrane. In general, however, any bone graft technique for repairing bone defects around a dental implant is called GBR. What are the key indications for GBR? Should every bony dehiscence around an implant be treated with GBR? It is important to clearly understand the indications of GBR in clinical implant dentistry. The need for GBR is determined by type and size of remaining bone wall. For example, when implants are placed immediately after tooth extraction, bone healing will be successfully achieved without GBR if all surrounding bony walls are intact. On the other hand, the necessity of GBR

\section{Young-Kyun Kim}

Department of Oral and Maxillofacial Surgery, Section of Dentistry, Seoul National University Bundang Hospital, 82 Gumi-ro 173beon-gil, Bundanggu, Seongnam 13620, Korea

TEL: +82-31-787-7541 FAX: +82-31-787-4068

E-mail:kyk0505@snubh.org

ORCID: https://orcid.org/0000-0002-7268-3870

(c) This is an open-access article distributed under the terms of the Creative Commons Attribution Non-Commercial License (http://creativecommons.org/ licenses/by-nc/4.0/), which permits unrestricted non-commercial use, distribution, and reproduction in any medium, provided the original work is properly cited.

Copyright (C) 2020 The Korean Association of Oral and Maxillofacial Surgeons. All rights reserved. increases as loss of bony wall increases. Briefly, GBR should be performed in cases of large defect or loss of bony wall. In cases of small defect, on the contrary, the prognosis may be better without bone graft ${ }^{1}$. A slight dehiscence $(<2 \mathrm{~mm})$ on the buccal side after implantation does not require GBR if the implant is secure with good primary stability ${ }^{2}$.

\section{Principles of GBR}

Wang and Boyapati ${ }^{3}$ suggested the PASS principle (P: primary closure, A: angiogenesis, S: space maintenance, S: stability) for successful GBR. The authors agree with this principle. Primary closure should be performed to prevent wound dehiscence as it can cause GBR failure due to increased risk of complications such as infection. An excellent blood supply at the recipient site can help achieve successful bone healing. In addition, the space should be secured during bone healing, with stabilization of the bone graft and barrier membrane.

\section{Necessity of Barrier Membranes}

Some research showed that use of a membrane did not affect the clinical outcomes if the clinician followed the principles of bone grafting. In particular, Gielkens et al. ${ }^{4}$ reported that the periosteum could function as a useful barrier membrane with osteogenic property. There has been controversy 
whether the barrier membrane benefits include reduced bone resorption ${ }^{5}$. The barrier membrane should be used in consideration of the clinical situation. The authors suggest that use of a barrier membrane is advantageous in cases of large bony defect and greater amount of bone grafts.

\section{Resorbable vs Non-Resorbable Membrane}

Each of the two membrane types (resorbable and nonresorbable) has its own pros and cons. The type of membrane does not affect the clinical outcome if the clinician carefully follows the principles of $\mathrm{GBR}^{5-8}$. Decomposition materials, generated during resorbable membrane resorption, may interfere with new bone formation and mechanical stability as a barrier membrane ${ }^{9}$. The resorbable membrane is not suitable for vertical bone augmentation because of its low rigidity and stability. However, the resorbable membrane has an advantage of resisting infection after wound dehiscence and maintaining space supported by grafting material ${ }^{10,11}$. The nonresorbable membrane has an excellent space maintenance property and predictable bone formation ability, although there is a high risk of infection with wound dehiscence ${ }^{12,13}$. Various resorbable and non-resorbable membranes have been used in implant dentistry. In particular, crosslinking and noncrosslinking materials are widely used for resorbable collagen membranes, while expanded-polytetrafluoroethylene (ePTFE) and high-density polytetrafluoroethylene (d-PTFE) are widely used for non-resorbable membranes. Although each product demonstrates its own characteristic, the clinical results were not significantly affected different by membrane type $^{14-16}$.

The types of resorbable membranes include collagen membranes, DynaMatrix extracellular membrane, acellular dermal matrix, polylactide/polyglycolide/N-methyl-2-pyrrolidone, and polyglactin $910^{16-22}$. Most non-resorbable membranes used include titanium mesh and polytetrafluoroethylene (PTFE) membrane $e^{13,23,24}$. The titanium meshes have been widely used in vertical and horizontal ridge applications because of their excellent stabilization and relatively good resistance to infection. To enhance bone formation capacity, a resorbable membrane is frequently applied to compensate for large pores in the titanium mesh ${ }^{13,25}$. A customized titanium mesh has been recently developed that is pre-bent according to various defect shapes and designed for easy handling and fixation $^{26,27}$. In the future, tissue engineering research will be actively conducted to develop a functional barrier membrane that can induce direct bone regeneration. Prior studies are quite extensive and include topics, for example, of a barrier membrane containing bone substitutes such as hydroxyapatite, growth factors/stem cells, organic/inorganic nanocompositions, and nanostructures ${ }^{28,29}$.

\section{Bone Graft Materials}

High-quality allogeneic graft materials have osteoinductive and osteoconductive healing potential, if they are manufactured from a proven tissue bank. On the other hand, poorquality allografts have not only a low bone healing potential but can promote infection and immune rejection. To achieve successful GBR, bone substitutes should be selected with high demineralized bone matrix content and mechanical stability. In addition, proper application of the barrier membrane is needed ${ }^{30-32}$. Xenografts and alloplastic bone substitutes have only osteoconductive healing potential and a slow resorption rate, which indicate an excellent space maintenance effect with volumetric stability ${ }^{33}$.

To overcome the disadvantages of autologous bone graft such as a large donor defect and high resorption rate, many clinicians have mixed such grafts with autologous bone and bone substitutes. These mixtures have showed excellent bone healing capacity with bone resorption if the mixture can secure stability via a barrier membrane. In addition, mixture with autologous bone facilitates rapid bone union and healing of bone substitutes ${ }^{34-36}$. The autologous bone can be collected by implant drilling as bone dust or harvested by bone scarper, trephine burr, micro-saw, and bone rongeur on adjacent bone, bony protuberance, torus, maxillary tuberosity, and mandibular ramus ${ }^{37}$. For effective reconstruction of severe bony dehiscence around a dental implant, the autologous bone should cover the implant, and xenografts or alloplastic bone substitutes are implanted above the autograft, covering the barrier membrane ${ }^{38,39}$.

\section{GBR and Implant Placement: Simultaneous vs Delayed}

If the implant can be secured to achieve primary stability, the clinical results are not affected by the timing of implant placement after GBR. However, in the case of poor primary stability due to severe bone defect, it is safe to provide a sufficient healing period between GBR and implant placement $^{40,41}$. 


\section{Cortical Bone Perforation}

The purpose of cortical bone perforation is to improve bone healing by enhancing blood supply to the graft as in the decertification concept ${ }^{42}$. Danesh-Sani et al. ${ }^{43}$ reported that larger cortical bone perforated holes results in greater new bone formation in the grafted site. However, some research reported controversial experimental results that cortical perforations did not improve bone healing or increase the amount of new bone matrix ${ }^{44}$. The authors suggest that cortical perforation is not necessary on the maxilla, as it is dominantly composed of cancellous bone with sufficient blood supply. Furthermore, we recommended performing cortical perforation in the mandible, consisting of thick cortical bone.

\section{Non-Submerged GBR}

For proper bony healing after GBR, intimate primary closure is one of the general principles. When wound dehiscence occurs, many complications follow, such as infection, bone loss, and poor wound healing. However, non-submerged GBR is a bone graft procedure to repair surrounding defects after transmucosal implant placement with intentional exposure of the upper portion of the implants and with primary gingival closure. It is controversial whether stable bone healing can be achieved with the non-submerged GBR. Recently, some researchers reported the effectiveness of the non-submerged $\mathrm{GBR}^{45-47}$. Primary stability of the implant is essential to achieve successful outcomes of the non-submerged GBR, and an intimate primary closure that covers the resorbable membrane also is important to achieve stable clinical outcomes.

\section{Complications}

Wound dehiscence and membrane exposure, which are the most common complications after GBR, could lead to postoperative infection, inadequate bony healing, and loss of graft materials. The causes of wound dehiscence are inadequate flap design, soft tissue tension, excessive graft material, trauma due to temporary denture, mastication, or tooth brushing. Upon membrane exposure, the amount of bone formation is reduced by seven-fold compared to a case without exposure. If GBR is performed to repair a dehiscence defect around the upper part of the implant, unsatisfactory bone healing often will be observed because the bone graft substitutes move toward the implant apex ${ }^{48-50}$. To prevent bone substitute migra- tion, many clinicians apply an additional membrane fixation method with membrane holding suture, bone pin or screw, and L-shape soft block bone directly on the dehiscence defect $\operatorname{area}^{50-52}$.

\section{Clinical outcome of GBR}

The long-term prognosis of implants with GBR is controversial $^{52}$. Some studies reported higher marginal bone loss on implants with GBR compared to those without $\mathrm{GBR}^{53,54}$. Hämmerle et al. ${ }^{55}$, Fiorellini et al. ${ }^{56}$, and Nakajima et al. ${ }^{57}$ reported that the prognosis of implants with GBR was not significantly different compared to that without GBR. However, Zitzmann et al. ${ }^{58}$ suggested that GBR should be performed on bone dehiscence defects $>2 \mathrm{~mm}$ because there was a mean bone loss of about $2 \mathrm{~mm}$ after GBR. The authors agree with Zitzmann et al.'s opinion ${ }^{58}$ that a criterion for GBR is a bony defect greater than $2 \mathrm{~mm}$.

\section{Summary}

To achieve successful GBR, the authors emphasize the following principles.

1) Adequate case selection and accurate evaluation of bony defects.

2) Maintenance of excellent blood supply.

3) Tension-free primary wound closure.

4) Stable membrane fixation.

5) Sufficient healing period: At least six months, and a longer healing period ( $\geq$ nine months) is recommended for larger defects.

6) If possible, mixing with autogenous bone can shorten the healing period and enhance new bone quality.

7) Special consideration should be taken in an aesthetic area or a scar region (where a previous surgery failed).

8) The experience and technique of the operator are important factors.

9) On large defects, it is safe to perform GBR first and place the implant second.

10) Infection management: Preventing infection is of utmost importance. If an infection occurs, early treatment should be performed, such as incision and drainage with antibiotics. 


\section{ORCID}

Young-Kyun Kim, https://orcid.org/0000-0002-7268-3870

Jeong-Kui Ku, https://orcid.org/0000-0003-1192-7066

\section{Authors' Contributions}

Y.K.K. participated in the literature review and wrote the primary manuscript. J.K.K. participated in the literature review and wrote the final manuscript.

\section{Conflict of Interest}

No potential conflict of interest relevant to this article was reported.

\section{References}

1. Jung RE, Herzog M, Wolleb K, Ramel CF, Thoma DS, Hämmerle $\mathrm{CH}$. A randomized controlled clinical trial comparing small buccal dehiscence defects around dental implants treated with guided bone regeneration or left for spontaneous healing. Clin Oral Implants Res 2017;28:348-54. https://doi.org/10.1111/clr.12806

2. Vanden Bogaerde L. A proposal for the classification of bony defects adjacent to dental implants. Int J Periodontics Restorative Dent 2004;24:264-71.

3. Wang HL, Boyapati L. "PASS" principles for predictable bone regeneration. Implant Dent 2006;15:8-17. https://doi.org/10.1097/01. id.0000204762.39826.0f

4. Gielkens PF, Bos RR, Raghoebar GM, Stegenga B. Is there evidence that barrier membranes prevent bone resorption in autologous bone grafts during the healing period? A systematic review. Int J Oral Maxillofac Implants 2007;22:390-8.

5. Urban IA, Nagursky H, Lozada JL, Nagy K. Horizontal ridge augmentation with a collagen membrane and a combination of particulated autogenous bone and anorganic bovine bone-derived mineral: a prospective case series in 25 patients. Int J Periodontics Restorative Dent 2013;33:299-307. https://doi.org/10.11607/prd.1407

6. Urban IA, Monje A, Lozada JL, Wang HL. Long-term Evaluation of peri-implant bone level after reconstruction of severely atrophic edentulous maxilla via vertical and horizontal guided bone regeneration in combination with sinus augmentation: a case series with 1 to 15 years of loading. Clin Implant Dent Relat Res 2017;19:4655. https://doi.org/10.1111/cid.12431

7. Jung RE, Fenner N, Hämmerle CH, Zitzmann NU. Long-term outcome of implants placed with guided bone regeneration (GBR) using resorbable and non-resorbable membranes after 12-14 years. Clin Oral Implants Res 2013;24:1065-73. https://doi.org/10.1111/ j.1600-0501.2012.02522.x

8. Basler T, Naenni N, Schneider D, Hämmerle CHF, Jung RE, Thoma DS. Randomized controlled clinical study assessing two membranes for guided bone regeneration of peri-implant bone defects: 3-year results. Clin Oral Implants Res 2018;29:499-507. https://doi.org/10.1111/clr.13147

9. Schliephake H, Dard M, Planck H, Hierlemann H, Jakob A. Guided bone regeneration around endosseous implants using a resorbable membrane vs a PTFE membrane. Clin Oral Implants Res 2000;11:230-41. https://doi.org/10.1034/j.1600$0501.2000 .011003230 . x$
10. Simion M, Jovanovic SA, Trisi P, Scarano A, Piattelli A. Vertical ridge augmentation around dental implants using a membrane technique and autogenous bone or allografts in humans. Int J Periodontics Restorative Dent 1998;18:8-23.

11. Tinti C, Parma-Benfenati S. Vertical ridge augmentation: surgical protocol and retrospective evaluation of 48 consecutively inserted implants. Int J Periodontics Restorative Dent 1998;18:434-43.

12. Simion M, Misitano U, Gionso L, Salvato A. Treatment of dehiscences and fenestrations around dental implants using resorbable and nonresorbable membranes associated with bone autografts: a comparative clinical study. Int J Oral Maxillofac Implants 1997;12:159-67.

13. Rakhmatia YD, Ayukawa Y, Furuhashi A, Koyano K. Current barrier membranes: titanium mesh and other membranes for guided bone regeneration in dental applications. J Prosthodont Res 2013;57:3-14. https://doi.org/10.1016/j.jpor.2012.12.001

14. Lee JY, Kim YK, Yun PY, Oh JS, Kim SG. Guided bone regeneration using two types of non-resorbable barrier membranes. J Korean Assoc Oral Maxillofac Surg 2010;36:275-9. https://doi. org/10.5125/jkaoms.2010.36.4.275

15. Kim YK, Ku JK. Ridge augmentation in implant dentistry. J Korean Assoc Oral Maxillofac Surg 2020;46:211-7. https://doi. org/10.5125/jkaoms.2020.46.3.211

16. Bunyaratavej P, Wang HL. Collagen membranes: a review. J Periodontol 2001;72:215-29. https://doi.org/10.1902/jop.2001.72.2.215

17. Oh TJ, Meraw SJ, Lee EJ, Giannobile WV, Wang HL. Comparative analysis of collagen membranes for the treatment of implant dehiscence defects. Clin Oral Implants Res 2003;14:80-90. https:// doi.org/10.1034/j.1600-0501.2003.140111.x

18. Kim YK, An YZ, Cha JK, Lee JS, Jung UW, Choi SH. Combined effects of a chemically cross-linked porcine collagen membrane and highly soluble biphasic calcium phosphate on localized bone regeneration. J Korean Dent Assoc 2018;56:667-85.

19. Nevins M, Nevins ML, Camelo M, Camelo JM, Schupbach P, Kim DM. The clinical efficacy of DynaMatrix extracellular membrane in augmenting keratinized tissue. Int J Periodontics Restorative Dent 2010;30:151-61.

20. Wei PC, Laurell L, Lingen MW, Geivelis M. Acellular dermal matrix allografts to achieve increased attached gingiva. Part 2. A histological comparative study. J Periodontol 2002;73:257-65. https:// doi.org/10.1902/jop.2002.73.3.257

21. Jung RE, Kokovic V, Jurisic M, Yaman D, Subramani K, Weber FE. Guided bone regeneration with a synthetic biodegradable membrane: a comparative study in dogs. Clin Oral Implants Res 2011;22:802-7. https://doi.org/10.1111/j.1600-0501.2010.02068.x

22. Gupta R, Pandit N, Sharma M. Clinical evaluation of a bioresorbable membrane (polyglactin 910) in the treatment of Miller type II gingival recession. Int J Periodontics Restorative Dent 2006;26:271-7.

23. Lindfors LT, Tervonen EA, Sándor GK, Ylikontiola LP. Guided bone regeneration using a titanium-reinforced ePTFE membrane and particulate autogenous bone: the effect of smoking and membrane exposure. Oral Surg Oral Med Oral Pathol Oral Radiol Endod 2010;109:825-30. https://doi.org/10.1016/j.tripleo.2009.12.035

24. Herzberg R. Vertical guided bone regeneration for a single missing tooth span with titanium-reinforced d-PTFE membranes: clinical considerations and observations of 10 consecutive cases with up to 36 months follow-up. Int J Periodontics Restorative Dent 2017;37:893-9. https://doi.org/10.11607/prd.3380

25. Cucchi A, Vignudelli E, Napolitano A, Marchetti C, Corinaldesi G. Evaluation of complication rates and vertical bone gain after guided bone regeneration with non-resorbable membranes versus titanium meshes and resorbable membranes. A randomized clinical trial. Clin Implant Dent Relat Res 2017;19:821-32. https://doi. org/10.1111/cid. 12520

26. Yu HC, Yun PY, Kim YK. Long-term observation of guided bone regeneration using preformed titanium mesh: a case series study. J 
Dent Implant Res 2019;38:39-47.

27. Hartmann A, Hildebrandt H, Schmohl JU, Kämmerer PW. Evaluation of risk parameters in bone regeneration using a customized titanium mesh: results of a clinical study. Implant Dent 2019;28:54350. https://doi.org/10.1097/ID.0000000000000933

28. Miron RJ, Fujioka-Kobayashi M, Buser D, Zhang Y, Bosshardt $\mathrm{DD}$, Sculean A. Combination of collagen barrier membrane with enamel matrix derivative-liquid improves osteoblast adhesion and differentiation. Int J Oral Maxillofac Implants 2017;32:196-203. https://doi.org/10.11607/jomi.5011

29. Karfeld-Sulzer LS, Weber FE. Biomaterial development for oral and maxillofacial bone regeneration. J Korean Assoc Oral Maxillofac Surg 2012;38:264-70. https://doi.org/10.5125/jkaoms.2012.38.5.264

30. Kim YK, Yun PY, Lim SC, Kim SG. Guided bone regeneration using Regenaform(R) and $\operatorname{Ossix}(\mathrm{R})$ membrane: three case reports. J Korean Assoc Oral Maxillofac Surg 2007;33:648-53.

31. Le BT, Borzabadi-Farahani A. Simultaneous implant placement and bone grafting with particulate mineralized allograft in sites with buccal wall defects, a three-year follow-up and review of literature. J Craniomaxillofac Surg 2014;42:552-9. https://doi. org/10.1016/j.jcms.2013.07.026

32. Kim YK, Kim SG, Lim SC, Lee HJ, Yun PY. A clinical study on bone formation using a demineralized bone matrix and resorbable membrane. Oral Surg Oral Med Oral Pathol Oral Radiol Endod 2010;109:e6-11. https://doi.org/10.1016/j.tripleo.2010.01.012

33. Camargo PM, Lekovic V, Weinlaender M, Vasilic N, Madzarevic M, Kenney EB. A reentry study on the use of bovine porous bone mineral, GTR, and platelet-rich plasma in the regenerative treatment of intrabony defects in humans. Int J Periodontics Restorative Dent 2005;25:49-59.

34. Kim YK, Kim SG, Lim SC. The comparative study of guided bone regeneration using various of bone graft materials. J Korean Assoc Oral Maxillofac Surg 2007;33:350-8.

35. Mordenfeld A, Johansson CB, Albrektsson T, Hallman M. A randomized and controlled clinical trial of two different compositions of deproteinized bovine bone and autogenous bone used for lateral ridge augmentation. Clin Oral Implants Res 2014;25:310-20. https://doi.org/10.1111/clr.12143

36. Hassan KS, Kassim A, Al Ogaly AU. A comparative evaluation of immediate dental implant with autogenous versus synthetic guided bone regeneration. Oral Surg Oral Med Oral Pathol Oral Radiol Endod 2008;106:e8-15. https://doi.org/10.1016/j.tripleo.2008.07.015

37. Lee SH, Yoon HJ, Park MK, Kim YS. Guided bone regeneration with the combined use of resorbable membranes and autogenous drilling dust or xenografts for the treatment of dehiscence-type defects around implants: an experimental study in dogs. Int J Oral Maxillofac Implants 2008;23:1089-94.

38. Van Assche N, Michels S, Naert I, Quirynen M. Randomized controlled trial to compare two bone substitutes in the treatment of bony dehiscences. Clin Implant Dent Relat Res 2013;15:558-68. https://doi.org/10.1111/j.1708-8208.2011.00408.x

39. Widmark G, Ivanoff CJ. Augmentation of exposed implant threads with autogenous bone chips: prospective clinical study. Clin Implant Dent Relat Res 2000;2:178-83. https://doi.org/10.1111/j.17088208.2000.tb00115.x

40. Kim YK, Yun PY, Im JH, Hwang JW, Lee HJ. Implant installation after guided bone regeneration: comparison between immediate and delayed group. J Korean Assoc Maxillofac Plast Reconstr Surg 2007:29:333-9.

41. Artzi Z, Nemcovsky CE, Tal H, Weinberg E, Weinreb M, Prasad $\mathrm{H}$, et al. Simultaneous versus two-stage implant placement and guided bone regeneration in the canine: histomorphometry at 8 and 16 months. J Clin Periodontol 2010;37:1029-38. https://doi. org/10.1111/j.1600-051X.2010.01621.x

42. Nishimura I, Shimizu Y, Ooya K. Effects of cortical bone perforation on experimental guided bone regeneration. Clin Oral
Implants Res 2004;15:293-300. https://doi.org/10.1111/j.16000501.2004.01001.x

43. Danesh-Sani SA, Tarnow D, Yip JK, Mojaver R. The influence of cortical bone perforation on guided bone regeneration in humans. Int J Oral Maxillofac Surg 2017;46:261-6. https://doi.org/10.1016/ j.ijom.2016.10.017

44. Barbosa DZ, de Assis WF, Shirato FB, Moura CC, Silva CJ, Dechichi P. Autogenous bone graft with or without perforation of the receptor bed: histologic study in rabbit calvaria. Int J Oral Maxillofac Implants 2009;24:463-8.

45. Liu R, Yang Z, Tan J, Chen L, Liu H, Yang J. Immediate implant placement for a single anterior maxillary tooth with a facial bone wall defect: a prospective clinical study with a one-year follow-up period. Clin Implant Dent Relat Res 2019;21:1164-74. https://doi. org/10.1111/cid.12854

46. Cafiero C, Annibali S, Gherlone E, Grassi FR, Gualini F, Magliano A, et al.; ITI Study Group Italia. Immediate transmucosal implant placement in molar extraction sites: a 12-month prospective multicenter cohort study. Clin Oral Implants Res 2008;19:476-82. https://doi.org/10.1111/j.1600-0501.2008.01541.x

47. Siciliano VI, Salvi GE, Matarasso S, Cafiero C, Blasi A, Lang NP. Soft tissues healing at immediate transmucosal implants placed into molar extraction sites with buccal self-contained dehiscences. A 12-month controlled clinical trial. Clin Oral Implants Res 2009;20:482-8. https://doi.org/10.1111/j.1600-0501.2008.01688.x

48. Kim YK, Yun PY. Risk factors for wound dehiscence after guided bone regeneration in dental implant surgery. Maxillofac Plast Reconstr Surg 2014;36:116-23. https://doi.org/10.14402/jkamprs.2014.36.3.116

49. Lim G, Lin GH, Monje A, Chan HL, Wang HL. Wound healing complications following guided bone regeneration for ridge augmentation: a systematic review and meta-analysis. Int J Oral Maxillofac Implants 2018;33:41-50. https://doi.org/10.11607/jomi.5581

50. Kim YK, Yun PY, Kim SG, Oh DS. In vitro scanning electron microscopic comparison of inner surface of exposed and unexposed nonresorbable membranes. Oral Surg Oral Med Oral Pathol Oral Radiol Endod 2009;107:e5-11. https://doi.org/10.1016/ j.tripleo.2009.03.003

51. Benic GI, Eisner BM, Jung RE, Basler T, Schneider D, Hämmerle CHF. Hard tissue changes after guided bone regeneration of periimplant defects comparing block versus particulate bone substitutes: 6-month results of a randomized controlled clinical trial. Clin Oral Implants Res 2019;30:1016-26. https://doi.org/10.1111/ clr. 13515

52. Lutz R, Neukam FW, Simion M, Schmitt CM. Long-term outcomes of bone augmentation on soft and hard-tissue stability: a systematic review. Clin Oral Implants Res 2015;26 Suppl 11:10322. https://doi.org/10.1111/clr.12635

53. Huang HY, Ogata Y, Hanley J, Finkelman M, Hur Y. Crestal bone resorption in augmented bone using mineralized freeze-dried bone allograft or pristine bone during submerged implant healing: a prospective study in humans. Clin Oral Implants Res 2016;27:e25-30. https://doi.org/10.1111/clr. 12512

54. Mengel R, Flores-de-Jacoby L. Implants in regenerated bone in patients treated for generalized aggressive periodontitis: a prospective longitudinal study. Int J Periodontics Restorative Dent 2005;25:331-41.

55. Hämmerle $\mathrm{CH}$, Jung RE, Feloutzis $\mathrm{A}$. A systematic review of the survival of implants in bone sites augmented with barrier membranes (guided bone regeneration) in partially edentulous patients. J Clin Periodontol 2002;29 Suppl 3:226-31; discussion 232-3. https://doi.org/10.1034/j.1600-051x.29.s3.14.x

56. Fiorellini JP, Kim DM, Nakajima Y, Weber HP. Osseointegration of titanium implants following guided bone regeneration using expanded polytetrafluoroethylene membrane and various bone fillers. Int J Periodontics Restorative Dent 2007;27:287-94.

57. Nakajima Y, Fiorellini JP, Kim DM, Weber HP. Regeneration of 
standardized mandibular bone defects using expanded polytetrafluoroethylene membrane and various bone fillers. Int J Periodontics Restorative Dent 2007;27:151-9.

58. Zitzmann NU, Schärer P, Marinello CP. Long-term results of implants treated with guided bone regeneration: a 5-year prospective study. Int J Oral Maxillofac Implants 2001;16:355-66.
How to cite this article: Kim YK, Ku JK. Guided bone regeneration. J Korean Assoc Oral Maxillofac Surg 2020;46:361-366. https:// doi.org/10.5125/jkaoms.2020.46.5.361 